Intan Berliana Putri Pratama ${ }^{1}$, Moses Glorino Rumambo Pandin ${ }^{2}$

${ }^{1}$ Fakultas Keperawatan, ${ }^{2}$ Fakultas Ilmu Budaya,

Universitas Airlangga

Jl. Dr. Ir. H. Soekarno, Mulyorejo, Kec. Mulyorejo, City of Surabaya, East Java 60115s

intan.berliana.putri-2020@fkp.unair.ac.id; moses.glorino@ fib.unair.ac.id

\title{
Book Review: \\ Treatise Between Civilizations The Future of Indonesian Democracy \\ (Risalah Antar Peradaban Masa Depan Demokrasi Indonesia)
}

Title: Risalah Antar Peradaban Masa Depan Demokrasi Indonesia; Author: Gafur Harun

Publisher: Literasi Nusantara; City of Rising: Batu; Edition: First Edition, December 2020; Number of pages: 142 pages; Book size: 15.5 cm X 23 cm; ISBN: 9786233290111

Democracy is a form of government adopted by Indonesia. Democracy is a form of government in which all citizens have the same rights in making decisions that can change their lives. The democracy adopted by the Indonesian nation is Pancasila democracy. Therefore, all of us need to know what Pancasila democracy is and how the relationship between Pancasila democracy and the millennial generation in the modern era like today.

The book entitled "Risalah Antar Peradaban Masa Depan Demokrasi Indonesia" was written by Harun Gafur and published by Literasi Nusantara in 2020. This book aims to be used in education and can be an effort to provide understanding to increase knowledge for readers.

Literacy is very important to be applied to Indonesian society in all circles. Because with literacy or reading a book, the mind will open. In addition, we can also gain a lot of knowledge and information from reading books. One of the books that we can read is a book entitled "Treatise Between Civilizations the Future of Indonesian Democracy (Risalah Antar Peradaban Masa Depan Demokrasi Indonesia)". It is intended for students, lecturers, and the general public interested in literacy to enrich their knowledge.

The author presents a different view of one dimension of civilization from another dimension of civilization. In general, it is discussing treatises on national democracy, religious civilization, the dynamics of socio-political civilization, and civic and political education.

The public needs to read this book because of the amount of information that can be obtained to increase knowledge that is in line with the development of the current era. In addition, it has an attractive cover, can be read by anyone, especially the millennial generation, and pages that are not too many so that they can be read when they have spare time.

Indonesia is a democratic country. In a democratic country, there must be freedom and recognition for its citizens. Therefore, education must have endeavored to develop and maximize existing potential based on the values of Pancasila. Education also aims so that citizens, especially the millennial generation who will lead the nation, do not make decisions based on personal interests and use various means. By obtaining education, the younger generation will lead Indonesia to the peak of its glory. The character of an appropriate leader must be trustworthy and based on Pancasila and the 1945 Constitution. In democratic life in Indonesia, many problems are created because of personal or group interests. Such as problems regarding politics, differences in religion, ethnicity, culture, and many more that can reduce the values of Pancasila.

The book was written because the author was interested in discussing civilization and democracy in Indonesia. The author states that the democratic system in Indonesia is still relatively weak. This weakness is reinforced by evidence, namely the weakness of public services in society caused by various things such as a paternalistic bureaucratic culture, a weak legal system, and a lack of commitment from local leaders. In addition, the author also raises 
the case of the struggle for a seat of power which is getting hotter every day and only occupied by certain groups. People are led to elect leaders by all means. This has led to a misguided democracy.

The evidence presented by the author of the case is compelling because we often hear a lot of news in the media regarding this case. Therefore, it requires cooperation from various parties and an effective strategy to return Pancasila democracy in the right direction. It is also necessary to make policies that can take advantage of new media such as electronic media because we have entered the modern era. This is where the millennial generation plays a role in understanding the values of Pancasila, the meaning of democracy in Indonesia, and the details of creating a prosperous nation in the future based on technology.

In running a country, a leader is needed. The author states that the leader must be aware of his obligation to serve the community for the sake of the nation and state, as described in chapter 2, page 49. Leaders must also know that Indonesia is a country that adheres to the ideology and democracy of Pancasila. So that it must be embedded in the values of Pancasila, especially the 1st precept. Indonesia has six recognized religions. However, each of these religions must also comply with the existing rules. Indonesia itself is a country with a large number of Muslims. So that there are often radical movements that want to overthrow the Republic of Indonesia's sovereignty, it is necessary to have a strong tolerance between religious communities that can unite the diversity of society in Indonesia to become a strong foundation for cooperation.

The role of the young generation of the Indonesian nation is significant for the country's sustainability in the future. Therefore, the young generation must be educated and get a decent education. In chapter 3, page 63, the author says that the multi and interdisciplinary social science approach is very important to be applied to students and students because it can provide understanding and knowledge. The younger generation also needs to be taught about citizenship education to have a national insight and participate in the life of the nation and state to make Indonesia a developed country in the future. Winataputra and Budimansyah (Encep Syarif Nurdin, 2015) explain that citizenship education has curricular, theoretical, and programming goals. In addition, the millennial generation also needs to be taught about political education. Political education can be carried out in various ways, such as political socialization by families, schools, or neighborhoods. The millennial generation can provide support and guidance to the government to produce the right on-target policies.

Indonesia is a democratic country. In a democratic country, there must be freedom and recognition for its citizens. Therefore, education must endeavor so that citizens can develop and maximize existing potential based on the values of Pancasila. Education also aims so that citizens, especially the millennial generation who will lead the nation, do not make decisions based on personal interests and use various means. By obtaining education, the younger generation will lead Indonesia to the peak of its glory. The character of an appropriate leader must be trustworthy and based on Pancasila and the 1945 Constitution. In democratic life in Indonesia, many problems are created because of personal or group interests. Such as problems regarding politics, differences in religion, ethnicity, culture, and many more that can reduce the values of Pancasila.

The purpose of this book is written to be used in education and can be an effort to provide understanding to increase knowledge for readers. It intended for students, lecturers, and the general public interested in literacy. This book fulfils the needs of its intended readers because the contents are pretty complete so that readers can add to the insights that have been obtained.

The book, entitled "Risalah Antar Peradaban Masa Depan Demokrasi Indonesia" can be said to be interesting to read. In this book, the author presents a different view of civilization in the democratic life of the Indonesian nation. In general, it discusses treatises on national democracy, religious civilization, the dynamics of socio-political civilization, and civic and political education. 
After reading it, readers will gain increased knowledge and understand civilization, the treatise of Pancasila democracy in Indonesia. This is very important because understanding civilization, the Pancasila democracy treatise, is the foundation for Indonesian citizens' lives in carrying out their lives.

In addition, this book can be pretty influential for readers because it discusses treatises on national democracy, religious civilization, the dynamics of socio-political civilization, and civic and political education so that there will be a high spirit of nationalism. The spirit of nationalism is a soul that all Indonesian citizens must own. Having a high spirit of nationalism will increase the unity and integrity of the nation. Examples of nationalism include loving Indonesia, being proud to be Indonesian citizens, and obeying regulations.

The style of writing the book can be said to be convoluted and quite confusing. The presented explanation tends to be complicated, and many choices of words are not right. In addition, between one chapter and another chapter is not continuous. It can be purchased in the form of an e-book as well as a physical book. The size is suitable for readers because it is not too large, making it easier to read.

In the explanation of the book there is something that the author ignores. Namely, in the introduction, a book by Samuel P. Huntington is mentioned, entitled "Benturan Antar Peradaban dan Masa Depan Politik Dunia". This book is not discussed in more detail by the author to be a consideration for the readers. Besides that, the book is a very suitable book to read for the public, especially Indonesian citizens, students, and lecturers. In general, it discusses treatises on national democracy, religious civilization, the dynamics of socio-political civilization, and civic and political education. The public needs to read this because of the amount of information that can be obtained to increase knowledge that is in line with the development of the current era. In addition, this book provides an attractive cover, can be read by anyone, especially the millennial generation, and pages that are not too many so that they can be read when they have spare time.

However, this book still has a flaw. There are many typos. In addition, the language used is too convoluted and quite challenging to understand. In addition, there are no pictures that can support learning. I hope this book's shortcomings can improve the quality of writing for other books in the future. So that both the millennial generation and the community can better complement their knowledge of Pancasila. I also highly recommend paying attention to the proper and correct punctuation and writing the right words to make no more mistakes.

Indonesia is a democratic country. The democracy that Indonesia currently adopts is Pancasila democracy. Because Indonesia has differences in it, it is essential to have a spirit of unity and oneness related to various aspects in Pancasila. The millennial generation is the nation's next generation which is predicted to bring Indonesia to its glory. Therefore, the millennial generation must understand Pancasila democracy and practice the values of Pancasila itself.

Intan Berliana Putri Pratama \& Moses Glorino Rumambo Pandin Universitas Airlangga

\section{REFERENCE}

1. Gafur H. Risalah Antar Peradaban Masa Depan Demokrasi Indonesia. Batu: Literasi Nusantara; 2020. 1-142 p.

\section{Author biography}

Harun Gafur is a man born in Waci, North Maluku. He studied undergraduate education at Khairun Ternate University and S2 at Yogyakarta State University. He has represented Indonesia at YOUTEX or the ASEAN Youth International Conference at Malaya University, Kuala Lumpur, Malaysia. Other books written include "Mahasiswa dan Dinamika Dunia Kampus", "Hukum Pidana Korporasi", and "Pendidikan Kewarganegaraan Prespektif Internasional". 